https://doi.org/10.46813/2020-130-200

\title{
HIGH VOLTAGE TEST BENCH FOR HEAVY ION BEAM PROBE DIAGNOSTICS ON T-15MD TOKAMAK
}

\author{
N.A. Vadimov ${ }^{1,2}$, G.A. Sarancha ${ }^{1,2}$, M.A. Drabinskiy ${ }^{1}$, A.V. Melnikov ${ }^{1,2,3}$, L.G. Eliseev ${ }^{1}$, \\ Ph.O. Khabanov ${ }^{I}$, N.K. Kharchev ${ }^{1,4}$, O.D. Komarov ${ }^{5}$ \\ ${ }^{1}$ NRC “Kurchatov Institute”, Moscow, Russia; \\ ${ }^{2}$ Moscow Institute of Physics and Technology, Moscow, Russia; \\ ${ }^{3}$ National Research Nuclear University “MEPhI", Moscow, Russia; \\ ${ }^{4}$ Prokhorov General Physics Institute, Moscow, Russia; \\ ${ }^{5}$ Institute of Plasma Physics NSC “Kharkov Institute of Physics and Technology”, Kharkiv, Ukraine
}

\section{E-mail: vadimov.na@phystech.edu}

\begin{abstract}
D-shaped tokamak T-15MD is nowunder construction in the NRC "Kurchatov Institute". Heavy ion beam probing (HIBP) is an important part of T-15MD diagnostic system. Calculations of the probing ions trajectories show that the beam will pass through the plasma about $1.0 \ldots 1.5 \mathrm{~m}$, which can lead to its significant attenuation. HIBP operation requires obtaininga high-current long-focus probing beam of $\mathrm{Tl}^{+}$ions $(\mathrm{I}=200 \ldots 400 \mu \mathrm{A}$, $\mathrm{f}=4 \ldots 6 \mathrm{~m}, \mathrm{~d} \leq 10 \mathrm{~mm})$. A high voltage $(300 \mathrm{keV})$ test-benchto test such beams is being created now. Numerical modeling shows the possibility of a beam formation with a current of $300 \mu \mathrm{A}$ and diameter $12 \mathrm{~mm}$ at $6 \mathrm{~m}$ from the ion emitter.
\end{abstract}

PACS: 52.70.Nc

\section{INTRODUCTION}

T-15MD $\quad\left(R=1.5 \mathrm{~m}, \quad a=0.67 \mathrm{~m}, \quad B_{t}=2 \mathrm{~T}\right.$, $\left.I_{p l}=2 \mathrm{MA}\right)$ is a D-shaped tokamak that is currently under construction in the National Research Center "Kurchatov Institute" [1]. Heavy ion beam probe was proposed to study plasma potential $\varphi[2]$, its fluctuations and also fluctuations of electron density $n_{e}$ and poloidal magnetic field $B_{p}$ [3]. HIBP is a unique tool to directly measure plasma potential in magnetically confined plasmas [4]. Measurements of plasma potential allow us to study radial electric field [5] and its coupling on transport processes including the transition to $\mathrm{H}$-mode [6]. This coupling has been studied during recent years, but it still presents an open question of modern plasma physics. As a multipurpose diagnostics HIBP is also used, to study Alfven eigen modes [7], turbulent flows [8] and plasma turbulence rotation [9, 10]. On top of that, plasma density profile can also be retrieved from the secondary beam current, which gives us an additional information to study the evolution of the plasma transport $[11,12]$.

The beam trajectory length in T-15MD is expected to be higher than those in T-10 (3.5 ..4 m) tokamak [13] and TJ-II stellarator [14], where HIBPs also operate. Estimations show that probing beam path through $\mathrm{T}-15 \mathrm{MD}$ plasma will be as long as $1.2 \ldots 1.5 \mathrm{~m}$ [15] With high plasma densities this will cause strong beam attenuation, which can lead to substantial signal loss. To operate HIBP with high beam attenuation, the beam intensity $\geq 200 \mu \mathrm{A}$ is required. Experiments show that for $\mathrm{Cs}^{+}$beams the current up to $300 \mu \mathrm{A}$ can be achieved [16].

To create $\mathrm{Tl}^{+}$beams a high-voltage test bench is being constructed. This test bench should mimic conditions of T-15MD experiment $(4 \ldots 6 \mathrm{~m}$ ion flight length, $\left.I_{\text {beam }}=200 \mu \mathrm{A}, E_{\text {beam }}=300 \mathrm{keV}\right)$.
New high capacity thermionic emitters are to be produced for HIBP operation on T-15MD. The capacity should allow an operation on $\sim 200 \mu \mathrm{A}$ for at least 1 week. The device for emitter manufacturing is also to be designed in assembly with the test bench.

\section{NUMERICAL MODELING}

The calculations of the beam path and thickness were done for the geometry of the beam injector, presented in Figs. 1, 2. At first the calculation of the electrostatic field of the electrodes inside the injector was carried out. Then the evaluation of self-consistent electric field and the tracing of a singly charged thallium ions beam was computed by an iterative method.At the current iteration there are two following steps: (i) tracing the ion beam through calculated electric field, (ii) computing the intrinsic electric field of the beam. At the next iteration, the particle beam is traced through the superposition of electrodes and the beam fields from the previous iteration. Practice has shown that the solution converges well at the third iteration. Total beam current was calculated according to the Child-Langmuir's law, following [16]. The model of a three-electrode lens (see Figs. 1, 2) was chosen as the basis for the experiment and its numerical simulation. Such three-electrode focusing system was developed and tested on the injector of HIBP diagnostic system at Uragan-2M stellarator in Kharkov, Ukraine in 2016-2017 [17, 18].

Numerical studies have shown the fundamental possibility of both creating a far-focused ion beam (in the region $U_{f o c}[-2.0 ;-4.0] \mathrm{kV}$ and $\left.U_{\text {extr }}[-1.0 ;-1.5]\right)$ for small beam currents (Fig. 3), and quasi-parallel (with a small angular divergence) for large ones (Fig. 4). To check these results an experimental bench is designed. 


\section{TEST BENCH DESIGN}

To verify numerical calculations of ion-optics system of the HIBP injector, a high-voltage $(300 \mathrm{kV} \geq U)$ test bench was designed. It allows tostudy ion-optics system and thermionic emitters' properties, including beam intensity, diameter and focal length. When the beam will be obtained, it can also be used for adjustment and calibration of the HIBP energy analyzer.

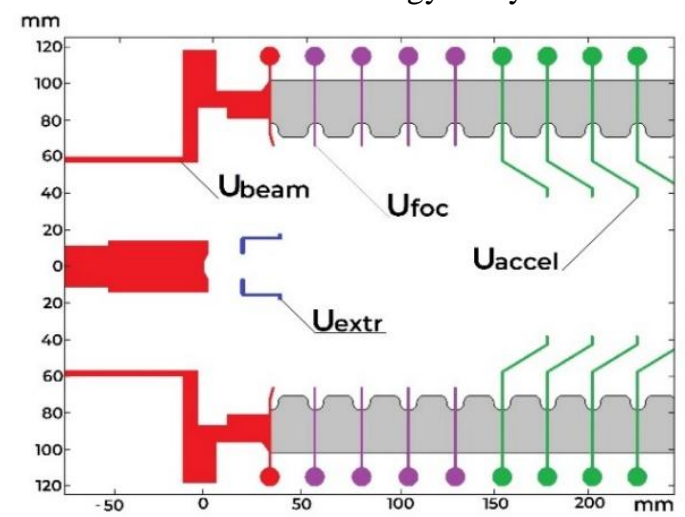

Fig. 1. Distribution of electrode potentials. Red $-300 \mathrm{kV}$ (High Voltage, $U_{\text {beam }}$ ), blue (extractor voltage, $U_{\text {extr }}$ ) and violet (focusing, $U_{f o c}$ ) are counted from $H V$, green-accelerating part $300 \cdot(1-N / 35) \mathrm{kV}$, where $N$ is the index number of electrode ring

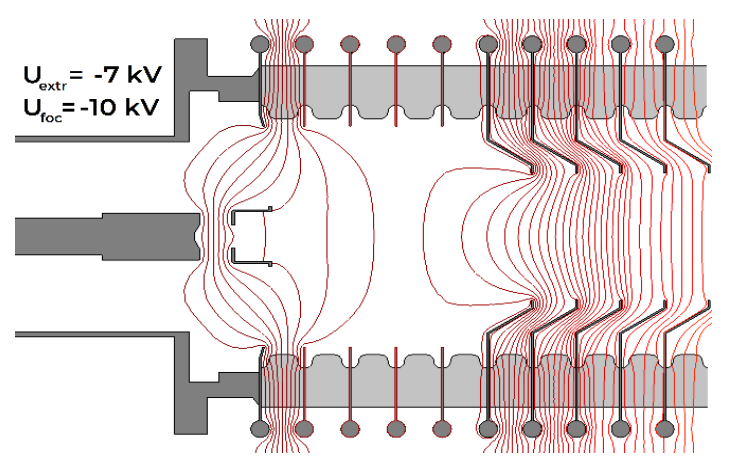

Fig. 2. Typical configuration of equipotential surfaces



Fig. 3. Focus distribution depending on focusing and extraction voltages for small beam currents

Fig. 5 demonstrates the design of the test bench. It consists of three main parts: HIBP injector, thebeamline and a $3 \mathrm{~m}$ long beam flight tube. Total length of beam trajectory is $5 \mathrm{~m}$, which is close to $\mathrm{T}-15 \mathrm{MD}$ conditions. The bench is placed on diagnostics platform of the T-10 tokamak and will use T-10 HIBP high voltage power supply.

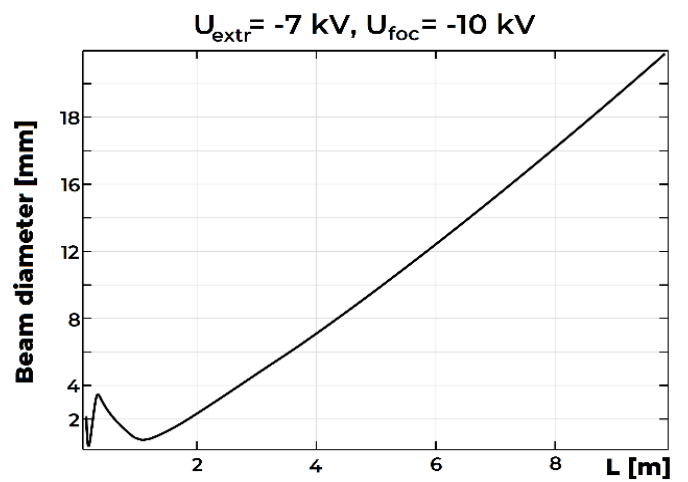

Fig. 4. Beam diameter along the trajectory at $U_{f o c}=-10 \mathrm{kV}, U_{\text {extr }}=-7 \mathrm{kV}, I_{\text {beam }}=275 \mu \mathrm{A}$



Fig. 5. Technical design of the high-voltage test bench: 1 - HIBP injector; 2 - beam-line; 3 - beam flight tube; 4 - vacuum pumping system; 5 - wire sensors; 6-Faraday cup

The whole system will be pumped out to high vacuum of $10^{-5} \ldots 10^{-6}$ Torr by two vacuum units, each equipped with two turbo-molecular pumps $(60 \mathrm{l} / \mathrm{s})$ and a backing vacuum pump. The vacuum system is able to provide high pumping rate to quickly adjust sensors and swap thermionic emitters.

The experiment (Fig. 6) is designed as follows: $\mathrm{Tl}^{+}$ ions extracted from the emitter are accelerated in the electric field of the injector to energies up to $E_{\text {beam }}=300 \mathrm{keV}$. The beam-line contains a pair of scanning plates that control beam direction. Changing beam direction back and forth, its focus length, size and profile can be measured using the set of wire sensors. The wire signal depends on beam-line deflecting plate's voltage.Ion signal peaks appear when the beam is crossing a wire. The Faraday cup placed at the end of the flight tube allows measurements of the beam current.

Fig. 7 demonstrates the current state of the test bench assembly. Next steps are connecting vacuum units, vacuum tests and installing the sensors.

Technology for the manufacture of zeolite thermionic thallium sources is underway now. It is foreseen the test of this technology and manufacturing the emitters at the manufacturing unit coupled to test bench through the vacuum system.

The manufacturing unit is shown in Figs. 8, 9. It will be equipped with regulated heating transformer 
220/20 V with high voltage insulation between transformer windings, the emitter heating power up to $350 \mathrm{~W}$ for emitters' manufacturing [17].

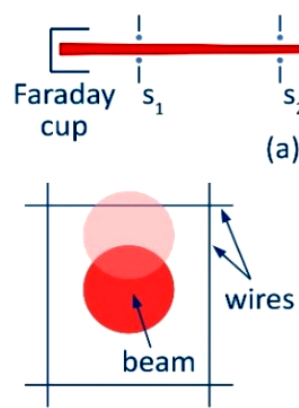

(b) (a)

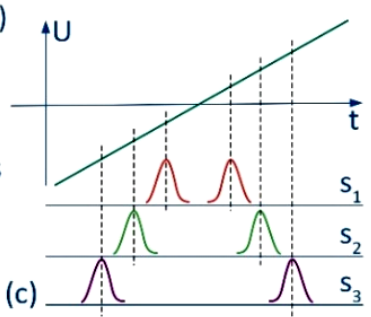

Fig. 6. The high-voltage test bench experiment scheme: $a$-beam trajectory in the flight tube, $s_{1-3}-$ wire sensors; $b$-beam profile in a wire sensor, pale-red circle - beam crossing the wire; $c$-dependency of signal on wire sensors on scanning voltage

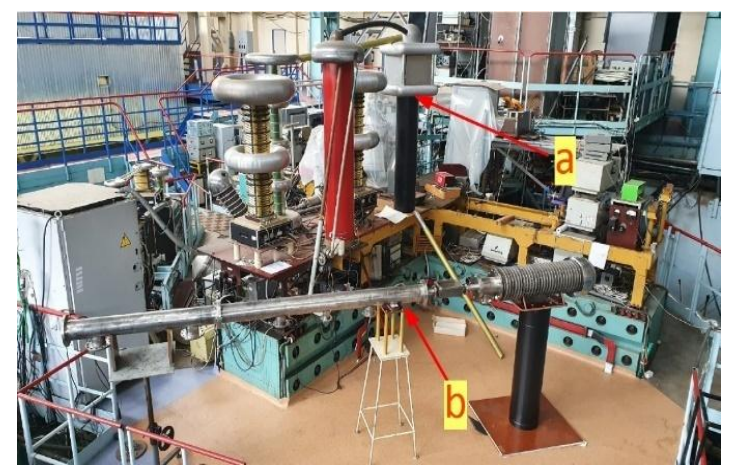

Fig. 7. Photo of the bench assembly: $a-T-10$ HIBP high-voltage power supply; $b$ - test bench

Emitter test includes two stages - ion current and beam mass-spectrum measurements. The extracting voltage is up to $10 \mathrm{kV}$ for emission ability testing.

The heating unit will be covered with $20 \mathrm{~mm}$ thick organic glass. Faraday cup will have a hole in order to visually control the emitter. Also, one more window with ordinary $10 \mathrm{~mm}$ thick glass will be placed near the emitter-extractor unit for visual control of the emitter manufacturing process.

The emitter's thallium zeolite powder is loaded into the cup of $8 \mathrm{~mm}$ diameter, $2 \mathrm{~mm}$ depth, made with $0.2 \ldots 0.3 \mathrm{~mm}$ thick tantalum. Then this cup is placed to the emitter heating filament and baked at $1250^{\circ} \mathrm{C}$. The emitter is ready when it reaches a uniform temperature over its surface.Ion current will be measured by Faraday cup with $100 \mathrm{k} \Omega$ load.

The beam mass-spectrum measurement will be carried out by applying $+200 \ldots+500 \mathrm{~V}$ to the emitter by pulse generator of locking voltage to the extractor with $50 \ldots 300 \mathrm{~V}$ amplitude and $30 \ldots 50 \mu$ s duration. The ion mass is detected by time-of-flight delay of the pulse ion current to an additional collector with $1 \mathrm{k} \Omega$ load. The time-of-flight distance must be as large as possible, approximately $0.5 \mathrm{~m}$.

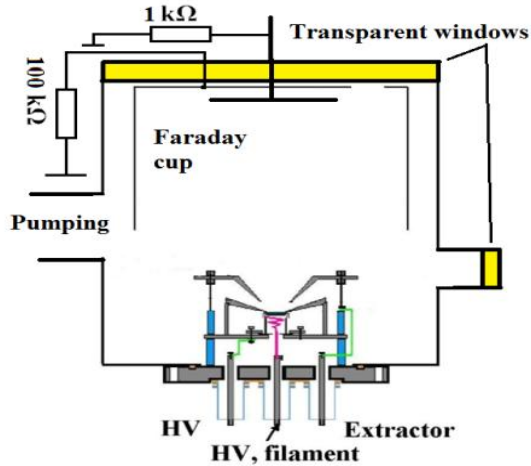

Fig. 8. Schematics of emitter manufacturing and testing unit

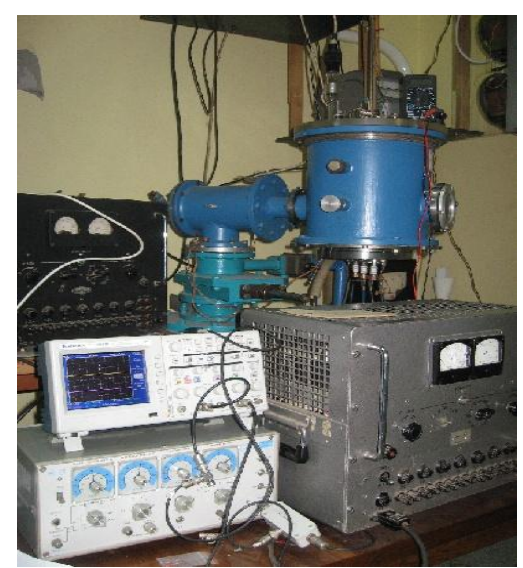

Fig. 9. Photo of the emitter manufacturing and testing unit

\section{CONCLUSIONS}

The high-voltage test-bench to study the features of the probing beam for T-15 MD HIBP is designed. It is aimed to simulate the expected experimental conditions of the machine $\left(L=6 \mathrm{~m}, E_{\text {beam }} \sim 300 \mathrm{keV}\right)$. Numerical modeling shows the capability to get high-intensity beam $(300 \mu \mathrm{A})$ with $12 \mathrm{~mm}$ diameter at $6 \mathrm{~m}$ from beam accelerator.

\section{ACKNOWLEDGEMENTS}

This work was supported byRussian Science Foundation project 19-12-00312. A.V. Melnikov was partly supported by the Competitiveness Program of NRNU MEPhI.

\section{REFERENCES}

1. A.V. Melnikov et al. Physical Program and Diagnostics of the T-15 Upgrade Tokamak // Fusion Engineering and Design. 2015, v. 96, 97, p. 306-310.

2. Yu.N. Dnestrovskij et al. Development of heavy ion beam probe diagnostics // IEEE Transaction Plasma Science. 1994, v. 22, p. 310-331. 
3. A.V. Melnikov et al. Heavy ion beam probing diagnostics to study potential and turbulence in toroidal plasmas // Nuclear Fusion. 2017, v. 57, p. 072004.

4. A.V. Melnikov. Applied and fundamental aspects of fusion science // Nature Physics. 2016, v. 12, p. 386390.

5. A.V. Melnikov. Electric Potential in Toroidal Plasmas // Springer Nature Switzerland AG. 2019, p. 240.

6. A.V. Melnikov et al. The changes in plasma potential and turbulent particle flux in the core plasma measured by heavy ion beam probe during L-H transitions in the TJ-II stellarator // Nuclear Fusion. 2013, v. 53, p. 092002.

7. A.V. Melnikov et al. Internal measurements of Alfvéneigenmodes with heavy ion beam probing in toroidal plasmas // Nuclear Fusion. 2010, v. 50, p. 084023.

8. L.G. Eliseev et al. Two point correlation technique for the measurements of poloidal plasma rotation by Heavy Ion Beam Probe // Plasma and Fusion Research. 2012, v. 7, p. 2402064.

9. L.G. Eliseev et al. Evaluation of Turbulent Particle Flux by Heavy Ion Beam Probe in the T-10 Tokamak // Plasma and Fusion Research. 2018, v. 13, p. 3402106.

10. A.V. Melnikov et al. Studies of poloidal rotation of plasma density turbulence with HIBP in the T-10 tokamak // 46th EPS Conf. on Plasma Physics (Milano, Italy, 2019) ECAv. 43A P5.1090.

11. Yu.N. Dnestrovskii et al. Density determination by probing with heavy-ion beams // Soviet Journal of Plasma Physics. 1986, v. 12, p. 130.
12. Ph.O. Khabanov et al. Density profile reconstruction using HIBP in ECRH plasmas in the TJ-II stellarator // Journal of Instrumentation. 2019, v. 14, p. C09033

13. A.V. Melnikov et al. Heavy ion beam probe design and operation on the T-10 tokamak // Fusion Engineering and Design. 2019, v. 146, Part A, p. 850853.

14. I.S. Bondarenko et al. Installation of an advanced heavy ion beam diagnostic on the TJ-II stellarator // Review of Scientific Instruments. 2001, v. 72, p. 583.

15. M.A. Drabinskiy et al. Conceptual design of the heavy ion beam probe diagnostic for the T-15MD tokamak // Journal of Instrumentation. 2019, v. 14, p. C11027.

16. L.I. Krupnik et al. High-Intensity Thermoionic Alkali Ion Sources for Plasma Diagnostics // IEEE Transaction Plasma Science. 2008, v. 36, p. 1536-1545.

17. O.D. Komarov et al. Estimations of Plasma Potential and Density by the Heavy Ion Beam Probing Diagnostics on the Uragan - 2M Torsatron // Problems of Atomic Science and Technology. Series «Plasma Physics». 2016, № 6, p. 306-309.

18. A.I. Zhezhera et al. A New Control Unit for Probing Ion Beam Forming in HIBP Diagnostic Systems // Problems of Atomic Science and Technology. Series «Plasma Physics». 2016, № 6, p. 310-313.

Article received 07.10.2020

\section{ВЫСОКОВОЛЬТНЫЙ СТЕНД ДЛЯ ИСПЫТАНИЯ ДИАГНОСТИКИ ЗОНДИРОВАНИЯ ПУЧКОМ ТЯЖЕЛЫХ ИОНОВ НА ТОКАМАКЕ Т-15МД}

\section{Н.А. Вадимов, Г.А. Саранча, М.А. Драбинский, А.В. Мельников, Л.Г. Елисеев, Ф.О. Хабанов, Н.К. Харчев, А.Д. Комаров}

В НИЦ «Курчатовский институт» ведется строительство токамака Д-образного сечения Т-15МД. Зондирование пучком тяжелых ионов (ЗПТИ) является важной частью его диагностического комплекса. Расчеты траекторий зондирующих ионов показывают, что пучок будет проходить по плазме путь длиной $1,0 \ldots 1,5$ м, что может приводить к значительному его затуханию. Возможность измерения параметров плазмы требует получения сильноточных длиннофокусных зондирующих пучков ионов $\mathrm{Tl}^{+}$ ( $\mathrm{I}=200 \ldots 400$ мкA, $\mathrm{f}=4 \ldots 6$ м, $\mathrm{d} \leq 10$ мм). Тестовый стенд для этой задачи сейчас создается. На этом стенде будут проводиться эксперименты по фокусировке ионных пучков с энергией до 300 кэВ, а также изучаться свойства термоионных эмиттеров и время их жизни. Расчеты движения заряженных частиц в ионнооптической системе инжектора показывают возможность создания пучка током 300 мкА, диаметром 12 мм на расстоянии 6 м от ионного эмиттера.

\section{ВИСОКОВОЛЬТНИЙ СТЕНД ДЛЯ ВИПРОБУВАННЯ ДІАГНОСТИКИ ЗОНДУВАННЯ ПУЧКОМ ВАЖКИХ ІОНІВ НА ТОКАМАЦІ Т-15МД}

\section{М.А. Вадимов, Г.А Саранча, М.А. Драбінський, О.В. Мельніков, Л.Г. Слісєєв, П.О. Хабанов, М.К. Харчев, О.Д. Комаров}

Зараз в НДЦ «Курчатовський інститут» ведеться будівництво токамака Д-образного перерізу Т-15МД. Зондування пучком важких іонів (ЗПВІ) є важливою частиною діагностичного комплексу Т-15МД. Розрахунки траєкторій зондувальних іонів показують, що пучок буде проходити у плазмі шлях довжиною $1,0 \ldots 1,5$ м, що може призводити до значного його ослаблення. Для забезпечення можливості вимірювань параметрів плазми потрібно отримати сильнострумових довгофокусних зондувальних пучків $\mathrm{Tl}^{+}$ $(\mathrm{I}=200 \ldots 400$ мкA, $\mathrm{f}=4 \ldots 6 \mathrm{~m}, \mathrm{~d} \leq 10 \mathrm{mм})$. На даний час у Курчатовському інституті створюється діагностичний стенд для вирішення цієї задачі. На цьому стенді будуть проводитися експерименти по фокусуванню іонних пучків з енергією до 300 кеВ, а також вивчатися властивості термоіонних емітерів і час їх життя. Розрахунки руху іонів в інжекторі показують можливість створення пучка струмом 300 мкА, діаметром 12 мм на відстані 6 м від іонного емітера. 